\title{
Efficacy of Water Extracts of Some Mangrove Plants for Eco-friendly Management of Root Rot Disease of Groundnut
}

\author{
Arjunan Muthukumar*, Ramasamy Naveenkunar and Arjunan Venkatesh \\ Department of Plant Pathology, Faculty of Agriculture, Annamalai University, Annamalainagar, Chidambaram, Tamil Nadu, India
}

\begin{abstract}
Root rot of groundnut caused by Macrophomina phaseolina causes significant losses in groundnut growing areas of Tamil Nadu. Hence, the present study was conducted to assess the prevalence and incidence of dry root rot of groundnut in different district of Tamil Nadu, India during 2013-14, assess the cultural characters and pathogenic variability among the isolates of $M$. phaseolina and to test the antifungal activity of water extracts from mangrove plants against pathogen. The results revealed that the maximum root rot incidence was observed $(30.33 \%)$ in Sivapuri village of $\left(\mathrm{I}_{3}\right)$ Cuddalore district. The disease incidence was more in, VRI2 variety and incidence was found to be more in sandy loam soils. Regarding the cultural characteristics revealed that the isolates $\mathrm{I}_{2}$ and $\mathrm{I}_{3}$ significantly recorded the maximum $(90 \mathrm{~mm})$ mycelial growth of $M$. phaseolina and the isolate $\mathrm{I}_{3}$ was found to be more virulent when compared to other isolates tested. Water extracts of nine mangrove plant species were screened against the root rot pathogen, M. phaseolina. Of these, Salicornia brachiata $(21.33 \mathrm{~mm})$, Rhizophora apiculata $(23.00 \mathrm{~mm})$ and Suaeda maritima $(26.33 \mathrm{~mm})$ were found to be highly effective against the test pathogen.
\end{abstract}

Keywords: Arachis hypogaea; Macrophomina phaseolina; Cultural characters; Water extracts from mangrove plants

\section{Introduction}

Groundnut (Arachis hypogaea L.), is an important leguminous oilseed crop, belonging to the family Fabaceae. Groundnut is called as the 'king' of oilseeds. It is grown in over 100 countries with a total estimated area of 21.8 million ha and with production of 28.5 million tons. In India, it is grown over an area of 4 lakh ha, with an annual production of 5.5 million tons and productivity of $1007 \mathrm{~kg} / \mathrm{ha}$ in the year 2009-10. China leads in production of peanuts, having a share of about $41.5 \%$ of overall world production, followed by India $(18.2 \%)$ and the United States of America (6.8\%) [1].

A large number of diseases attack groundnut in India [2,3]. The majorities are caused by fungi and several of them are yield reducers in certain regions and seasons [4]. Of these diseases, root rot caused by Macrophomina phaseolina (Tassi.) Goid. is an important pathogen of groundnut, distributed worldwide and causes considerable losses [5]. This disease causes severe damage during any stage of crop growth, and yield losses over $25 \%$ have been reported [2]. The fungus causes complex disease syndromes like charcoal rot of stem, root rot, seedling blight, foliage blight, dry rot, pod and seed rot.

The management of $M$. phaseolina, the causal agent of root rot was a difficult task, attempts were made to manage the root rot using different fungicides. But the indiscriminate use of fungicides resulted in the accumulation of residual toxicity in soil, environmental pollution and altered the biological balance in the soil by decimating the nontarget and beneficial microorganisms. Development of fungicides resistance in the pathogen has also been reported [6].

Recent efforts have focused on developing environmentally safe, long-lasting and effective marine plant extracts for the management of root rot disease. The recent research evidenced that Indian mangroves contained antibacterial [7] and antifungal [8] properties. Until now, more than 200 bioactive metabolites have been isolated from true mangroves of tropical and subtropical populations [9]. According to their chemical structure, most of the isolated compounds belong to steroids, triterpenes, saponins, flavonoids, alkaloids, tannins and phenolics which having a wide range of therapeutic possibilities [10].
During the recent years this disease causes significant losses in groundnut growing areas of Tamil Nadu. The objectives of the present study were (1) To assess the prevalence and incidence of dry root rot of groundnut in different district of Tamil Nadu, India during 201314 (2) Isolation, identification of pathogen and prove pathogenicity (3) To study the cultural characteristics of M. phaseolina isolates (4) To test the antifungal activity of mangrove plant extracts against $M$. phaseolina.

\section{Materials and Methods}

\section{Survey on the root rot incidence of groundnut in different districts of Tamil Nadu}

A field survey was conducted to assess the extent of root rot occurrence of groundnut in four districts of Tamil Nadu representing seven villages (Cuddalore, Erode, Karur and Thiruvannamalai). The villages where groundnut is traditionally grown are selected for assessing the prevalence of root rot disease caused by M. phaseolina. The per cent disease incidence was worked out as per Phytopathometry [11]. Also, the infected plants showing the typical symptoms of root rot due to infection with $M$. phaseolina were collected along with rhizosphere soil for isolation of the pathogen. The other information's regarding the soil type in which the crop is grown and the variety of groundnut cultivated were also recorded in the respective survey fields (Figure 1).

*Corresponding author: Arjunan Muthukumar , Department of Plant Pathology Faculty of Agriculture, Annamalai University, Annamalainagar, Chidambaram, Tami Nadu, India, Tel: +91 4144238 282; E-mail: muthu78ap@yahoo.co.in

Received: May 09, 2014; Accepted November 24, 2014; Published November 26, 2014

Citation: Muthukumar A, Naveenkunar R, Venkatesh A (2014) Efficacy of Water Extracts of Some Mangrove Plants for Eco-friendly Management of Root Rot Disease of Groundnut. J Plant Pathol Microb 5: 243. doi:10.4172/2157 7471.1000243

Copyright: (C) 2014 Muthukumar A, et al. This is an open-access article distributed under the terms of the Creative Commons Attribution License, which permits unrestricted use, distribution, and reproduction in any medium, provided the original author and source are credited. 
Citation: Muthukumar A, Naveenkunar R, Venkatesh A (2014) Efficacy of Water Extracts of Some Mangrove Plants for Eco-friendly Management of Root Rot Disease of Groundnut. J Plant Pathol Microb 5: 243. doi:10.4172/2157-7471.1000243

\section{Isolation and identification of pathogen}

The pathogen M. phaseolina was isolated from the diseased roots of groundnut plants showing the typical root rot symptoms by tissue segment method [12] on potato dextrose agar (PDA) medium. The axenic cultures of the different isolates of the pathogen were obtained by single hyphal tip method [12] and these were maintained on PDA slants. The identification was done based on the Barnett and Hunter, 1972 (Figures 2 and 3).

\section{Mass multiplication of M. phaseolina}

The isolates of the pathogen were multiplied in sand maize medium [13]. Sand and ground maize seeds were mixed in the ratio of 19:1, moistened to $50 \%$ level, filled in $500 \mathrm{ml}$ conical flask and autoclaved at 20 psi for 2 hrs. Young actively growing mycelial discs $(7 \mathrm{~mm})$ of the M. phaseolina isolates were obtained from four days old culture and inoculated into each flask under aseptic condition and the flasks were incubated at room temperature $\left(28 \pm 2^{\circ} \mathrm{C}\right)$ for 15 days. The inoculum thus obtained was used for the experiments (Figure 4).

\section{Assessing the virulence of $M$. phaseolina isolates}

The pot mixture was prepared by thoroughly mixing clay loam soil, sand and farm yard manure at the ratio of 1:1:1. The inoculum of each isolate of $M$. phaseolina collected from different locations were separately mixed @ 5\% (w/w) with the sterilized soil filled in $15 \times 30 \mathrm{~cm}$ dia earthen pots 10 days before sowing [14]. Groundnut seeds (VRI2)

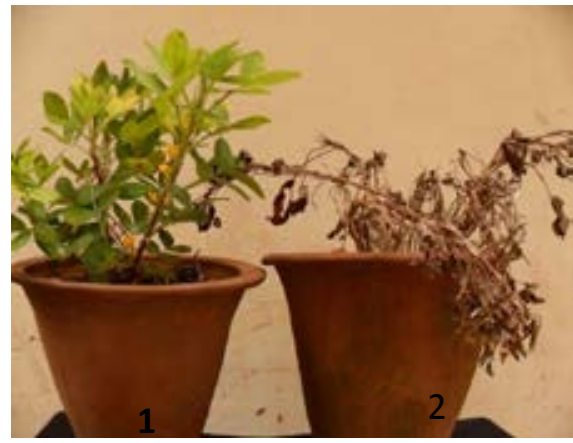

1.Healthy 2.Infected

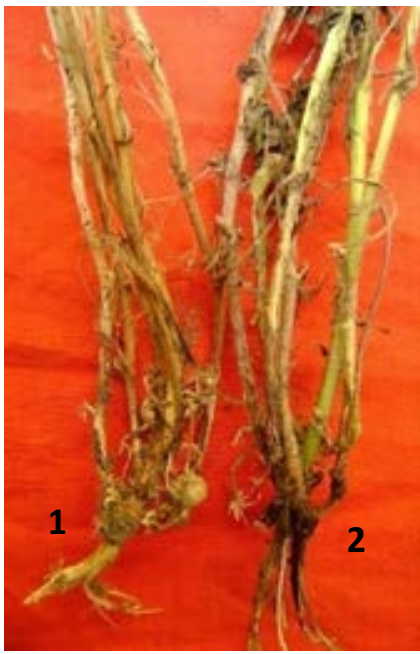

1.Healthy

2.Infected

Figure 1: Symptoms of root rot of groundnut.
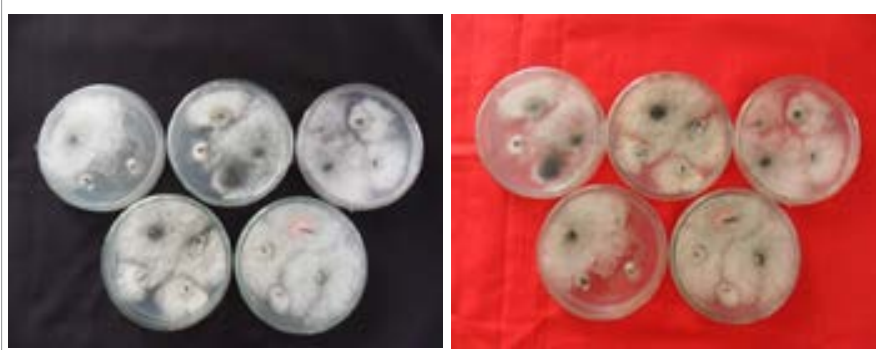

Figure 2: Isolation of pathogen.

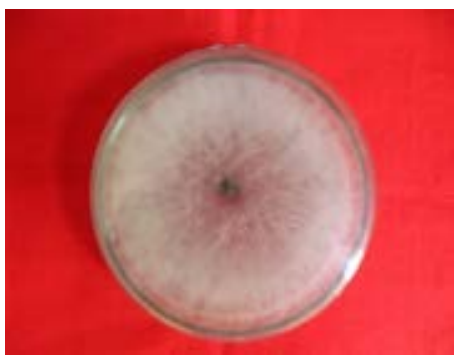

(three days old)

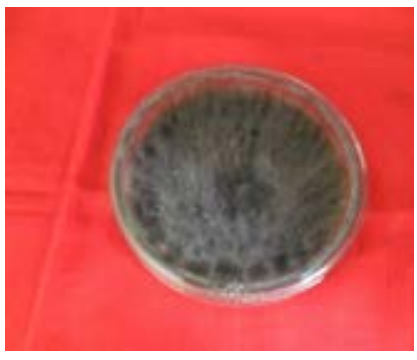

(six days old)
Figure 3: Axenic culture of Macrophomina phaseolina.

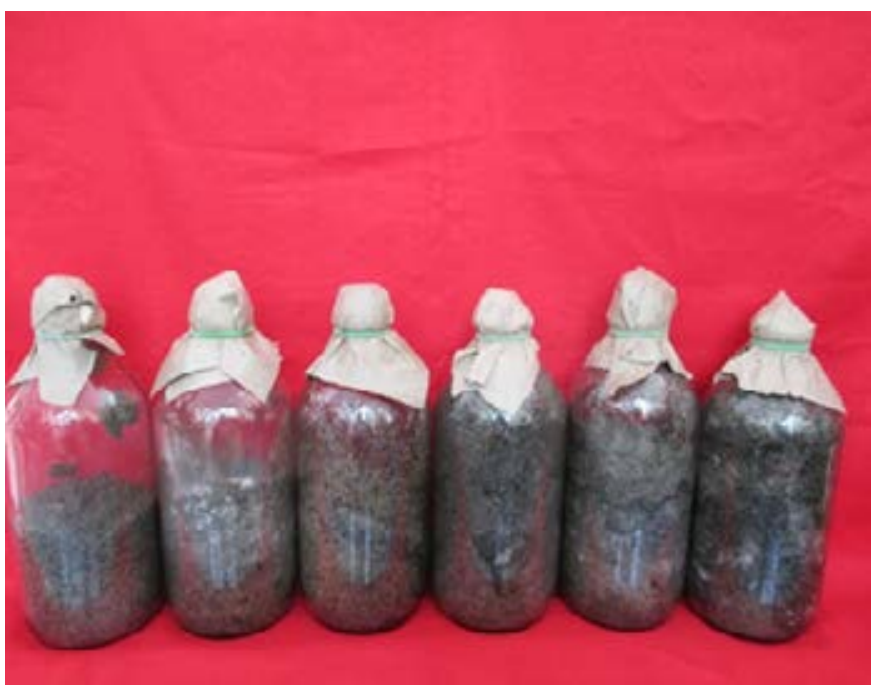

Figure 4: Mass multiplication of Macrophomina phaseolina isolates. surface sterilized with mercuric chloride solution @ $0.1 \%$ for $30 \mathrm{sec}$. followed by two washings in sterile distilled water and sown @ 3 seeds/ pot. The experiment was conducted in a completely randomized block design with three replications. The pots were maintained in glass house with regular, judicious and uniform watering. The root rot incidence was recorded at 50 and 75 DAS (Days after sowing) and the per cent disease incidence was calculated.

\section{Cultural characteristics of the isolates}

Mycelial growth: Fifteen $\mathrm{ml}$ of the sterile PDA medium was poured into sterile Petri dishes and allowed to solidify. A seven $\mathrm{mm}$ culture disc of $M$. phaseolina obtained from actively growing region 
was aseptically placed at the centre of the Petri plate and incubated at room temperature $\left(28 \pm 2^{\circ} \mathrm{C}\right.$ ). The radial growth (in $\mathrm{mm}$ ) and colour of the isolates measured four days after inoculation.

\section{Antimycotic effect of mangrove leaf extracts against $M$.} phaseolina $\left(\mathrm{I}_{3}\right)$

Collection of plant extracts: A total of nine mangrove leaf extracts were collected from mangrove forest pichavaram, cuddalore. The list of mangrove plant species were given in Table 1.

Preparation of leaf extracts (water): Fresh leaves of nine different plant species were collected in and around Pichavaram mangroves and used for extraction. The leaves were first washed with distilled water and finally with sterile distilled water, ground in a pestle and mortar by adding sterile distilled water at the ratio of $1: 1(\mathrm{w} / \mathrm{v})$. The macerate was squeezed using cotton wool to get the extract. The extracts were filtered through two layers of muslin cloth, through Whatman No.1 filter paper and finally through the bacteriological filter. This formed the standard plant extract solution (100\%). This was further diluted with the sterile distilled water (v/v) to have the required $20 \%$ concentration [15].

\section{Efficacy of mangrove leaf extracts against $M$. phaseolina} under in vitro

The agar-well diffusion method was used to determine the antimicrobial activity of the extracts [16,17]. The potato dextrose agar (PDA) medium was poured into sterilized plates and allowed to cool. The wells were formed in the Petri plates on four sides using cork borer. Then, the $20 \%$ plant extract $(100 \mu \mathrm{l})$ was delivered into wells $(8$ $\mathrm{mm}$ diameter) of the already seeded PDA medium. The plates were inoculated with $M$. phaseolina. The diameter of the mycelial colony was measured 4 days after inoculation. The medium without plant extracts served as control and the mean percentage of inhibition was worked out.

\section{Statistical Analysis}

All the experiments were of completely randomized design (CRD) and repeated twice. To determine the effect of each bioagents on the radial growth of pathogen, the per cent reduction compared with the experimental controls was calculated. Data were subjected to analyses of variance and treatment means were compared by an appropriate Duncan's multiple range test $(\mathrm{P}<0.05)$. The IRRISTAT package version 92.1, developed by the International Rice Research Institute Biometrics Unit, Philippines, was used for analysis [18].

\section{Results and Discussion}

\section{Survey on the incidence of root rot incidence}

The data presented in Table 2 on the survey in different districts of Tamil Nadu revealed the endemic nature of the root rot disease incidence. Among the different places surveyed for groundnut root rot incidence, Sivapuri $\left(\mathrm{I}_{3}\right)$ registered the maximum incidence of the disease (30.33\%) followed by Pichavaram ( $\mathrm{I}_{1}$ ) with $28.66 \%$ and Ramapuram $\left(\mathrm{I}_{2}\right)$ with $24.33 \%$. The other locations had moderate disease incidence while the minimum root rot incidence of $18.00 \%$ was recorded in Kilpalur (Table 2). In general, the crop grown under rainfed conditions showed more root rot incidence when compared with the crops grown under irrigated conditions. In respect of soil type, sandy loam had more root rot incidence (23.66 to $30.33 \%$ ) than clay loam (18.00 to $21.00 \%$ ) soil. The local cultivars of groundnut recorded comparatively lesser (18.00\%) root rot incidence than the improved cultivars viz., VRI2 and JL24 (20.33 to $30.33 \%$ of disease incidence, respectively).

The variation in the extent of the disease incidence might be due to the prevalence of the isolates of the pathogen differing in their virulence as observed in the present study. Similar such endemic nature of root rot disease of groundnut in Gujarat was reported [19]. The dry condition prevalent in the rain fed conditions might have favoured the pathogen which could be attributed for the higher level of disease incidence. It has been reported that dry rainfed conditions favored higher root rot disease in crops [20]. The disease incidence was more in sandy loam as compared to clay loam (Table 2). The root rot disease caused by $R$. bataticola in cowpea was the maximum in sandy soil while it was the minimum in clay soil [21]. Similar observations with M. phaseolina in mungbean [22] and sesame [23] have been reported. Higher incidence

\begin{tabular}{|c|c|c|c|c|c|}
\hline SI. No. & Common name & Botanical name & Family & Habit & Parts used \\
\hline 1. & Adappankodi & Ipomoea pescaprae L. & Convolvulaceae & Herb & Leaf \\
\hline 2. & Karungkandal & Avecennia officinalis $\mathrm{L}$. & Avicenniaceae & Shrub & Leaf \\
\hline 3. & Katumari & Salicornia brachiata Roxb & Chenopodiaceae & Herb & Leaf \\
\hline 4. & Kozhikal & Salicornia brachiata. & Chenopodiaceae & Herb & Leaf \\
\hline 5. & Neermulli & Acanthus ilicifolius L. & Acanthaceae & Herb & Leaf \\
\hline 6. & Sangam & Clerodendron inerme Gaertn. & Verbenaceae & Shrub & Leaf \\
\hline 7. & Surapunnai & Rhizophora apiculata Blume. & Rhizophoraceae & Tree & Leaf \\
\hline 8. & Surapunnai & Rhizophora apiculata Blume. & Rhizophoraceae & Tree & Leaf \\
\hline 9. & Umiri & Suaeda maritima (Linn.)Dum & Chenopodiaceae & Herb & Leaf \\
\hline
\end{tabular}

Table 1: List of mangrove plants used for the present study.

\begin{tabular}{|c|c|c|c|c|}
\hline SI.No. & Name of the District & Name of the Village & Soil type & Variety \\
\hline 1. & Cuddalore & Pichavaram & Sandy loam & VRI-2 \\
\hline 2. & Cuddalore & Ramapuram & Sandy loam & VRI-2 \\
\hline 3. & Cuddalore & Sivapuri & Sandy loam & VRI-2 \\
\hline 4. & Erode & Salaipudhur & Clay loam & JL-24.33 b \\
\hline 5. & Karur & Lingathur & Sandy loam & VRI-2 \\
\hline 6. & Thiruvannamalai & Chinnaiyampatti & Clay loam & JL \\
\hline 7. & Thiruvannamalai & Kilpalur & Clay loam & 23.33 c \\
\hline
\end{tabular}


Citation: Muthukumar A, Naveenkunar R, Venkatesh A (2014) Efficacy of Water Extracts of Some Mangrove Plants for Eco-friendly Management of Root Rot Disease of Groundnut. J Plant Pathol Microb 5: 243. doi:10.4172/2157-7471.1000243

Page 4 of 6

of the disease in sandy soils might be attributed to the less competitive saprophytic ability (CSA) of the pathogen at high moisture holding capacity (MHC) associated with heavy soils like clay [24] and reduction in the germination of sclerotia of $M$. phaseolina at high MHC (Figure 5) [25]. The survey in different locations of Cuddalore district revealed the endemic nature of the root rot disease incidence with the maximum incidence of the disease (31.68\%) registered in Vengatakuppam (MP18) location. The disease incidence was more in improved cultivars like, VRI2, JL24; more in sandy loam soils and rainfed condition [26].

\section{Assessing the virulence of M. phaseolina isolates}

The data depicted in Table 3 revealed that the level of pathogen varied between the isolates. Among the seven isolats of $M$. phaseolina the isolate- $\mathrm{I}_{3}$ (Sivapuri) recorded the maximum disease incidence of $40.00 \%$ at 75 DAS (Days after sowing). It was followed by the isolate- $I_{2}$ (Ramapuram). The isolate- $\mathrm{I}_{7}$ (Kilpalur) recorded the least incidence of root rot disease recording $12.33 \%$. The isolate- $\mathrm{I}_{3}$ was found to be more virulent when compared to other isolates. Hence, the isolate- $\mathrm{I}_{3}$ alone taken for the subsequent experiments.

The variability in the pathogenecity among the isolates of $M$. phaseolina was reported by several workers [6,23] with different crops. The occurrence of $26 \mathrm{M}$. phaseolina isolates from 11 different localities of green gram growing areas in India was reported [27]. The above reports are in agreement with the present investigation. Similar observations were made by [28] in sunflower, [14] in sesame; [29] in rice fallow blackgram; [26] in groundnut. Thus, the observations of the present survey indicated the endemic nature of groundnut root rot disease in Cuddalore District of Tamil Nadu, India.

\section{Cultural characteristics of M. phaseolina isolates}

All the seven isolates of the root rot pathogen M. phaseolina produced cottony white or dull white mycelial growth on PDA medium. The isolates $\mathrm{I}_{1}$ and $\mathrm{I}_{3}$ significantly recorded the maximum (90 $\mathrm{mm})$ mycelial growth, while it was the minimum $(74.33 \mathrm{~mm})$ in the case of $\mathrm{I}_{7}$ (Table 4).

Similar variations in the mycelial growth among the isolates of $M$. phaseolina were observed by earlier workers [30,31]; The results of the present experiment also revealed that the isolates of $M$. phaseolina with faster mycelial growth were more pathogenic and produced higher incidence of the disease. The virulence of the isolates of M. phaseolina was positively correlated with their growth rate [32]. Isolates of M. phaseolina with faster mycelial growth were found more

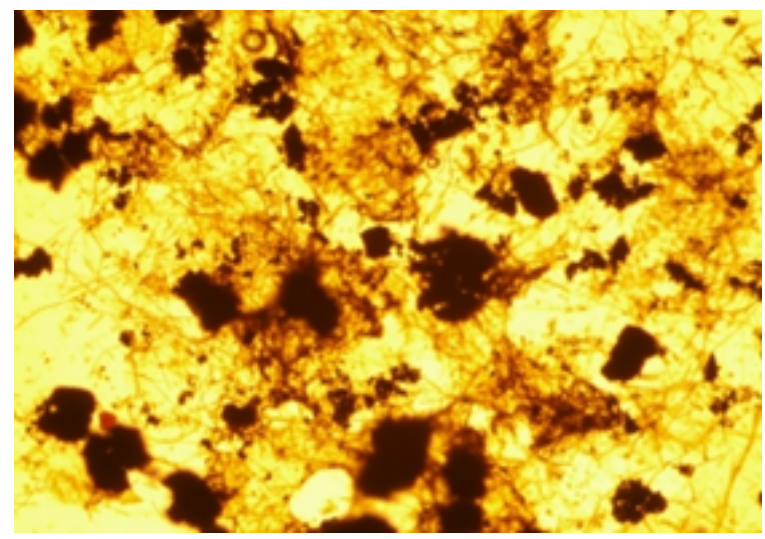

Figure 5: Sclerotia of Macrophomina phaseolina.

\begin{tabular}{|c|c|c|c|}
\hline \multirow{2}{*}{ SI. No. } & \multirow{2}{*}{ M. phaseolina isolates } & \multicolumn{2}{|c|}{ Root rot incidence (\%) } \\
\cline { 3 - 4 } & & $\mathbf{5 0}$ DAS $^{*}$ & $\mathbf{7 5}$ DAS* \\
\hline 1. & $\mathrm{I}_{1}$ & $26.00{ }^{* *} \mathrm{~b}$ & $37.66{ }^{* *} \mathrm{~b}$ \\
\hline 2. & $\mathrm{I}_{2}$ & $25.33 \mathrm{~b}$ & $35.00 \mathrm{c}$ \\
\hline 3. & $\mathrm{I}_{3}$ & $28.66 \mathrm{a}$ & $40.00 \mathrm{a}$ \\
\hline 4. & $\mathrm{I}_{4}$ & $16.33 \mathrm{~d}$ & $26.00 \mathrm{e}$ \\
\hline 5. & $\mathrm{I}_{5}$ & $20.00 \mathrm{C}$ & $31.33 \mathrm{~d}$ \\
\hline 6. & $\mathrm{I}_{6}$ & $13.66 \mathrm{e}$ & $22.00 \mathrm{f}$ \\
\hline 7. & $\mathrm{I}_{7}$ & $12.33 \mathrm{f}$ & $16.00 \mathrm{~g}$ \\
\hline
\end{tabular}

*Means of three replications; DAS-Days after sowing

**The means followed by a common letter are not significantly different at $P=0.05$ by DMRT

Table 3: Assessing the virulence of Macrophomina phaseolina isolates.

\begin{tabular}{|c|c|c|c|}
\hline SI. No. & $\begin{array}{c}\text { M. phaseolina } \\
\text { isolates }\end{array}$ & $\begin{array}{c}\text { Mycelial } \\
\text { growth }(\mathbf{m m})^{*}\end{array}$ & Mycelial characters \\
\hline 1. & $\mathrm{I}_{1}$ & $83.33^{* *} \mathrm{C}$ & Black profusely aerial growth \\
\hline 2. & $\mathrm{I}_{2}$ & $90.00 \mathrm{a}$ & Black profusely aerial growth \\
\hline 3. & $\mathrm{I}_{3}$ & $90.00 \mathrm{a}$ & Grey profusely aerial growth \\
\hline 4. & $\mathrm{I}_{4}$ & $80.33 \mathrm{~d}$ & Grey profusely aerial growth \\
\hline 5. & $\mathrm{I}_{5}$ & $86.66 \mathrm{~b}$ & White grey profusely aerial growth \\
\hline 6. & $\mathrm{I}_{6}$ & $84.00 \mathrm{C}$ & White grey profusely aerial growth \\
\hline 7. & $\mathrm{I}_{7}$ & $74.33 \mathrm{e}$ & Black profusely aerial growth \\
\hline
\end{tabular}

*Means of three replications

** The means followed by a common letter are not significantly different at $\mathrm{P}=0.05$ by DMRT

Table 4: Cultural characteristics of Macrophomina phaseolina isolates.

\begin{tabular}{|c|c|c|c|}
\hline SI.No. & Mangrove leaf extracts & $\begin{array}{c}\text { Radial mycelial } \\
\text { growth } \mathbf{( m m})^{*}\end{array}$ & $\begin{array}{c}\text { Per cent inhibition } \\
\text { over control }\end{array}$ \\
\hline 1. & Ipomoea pescaprae L. & $32.66^{* *} \mathrm{~d}$ & 63.16 \\
\hline 2. & Avecennia officinalis L. & $44.33 \mathrm{f}$ & 50.00 \\
\hline 3. & Salicornia brachiata Roxb & $21.33 \mathrm{ha}$ & 76.00 \\
\hline 4. & Salicornia brachiata. & $50.00 \mathrm{j}$ & 43.60 \\
\hline 5. & Acanthus ilicifolius L. & $28.00 \mathrm{c}$ & 68.41 \\
\hline 6. & Clerodendron inerme Gaertn. & $39.66 \mathrm{e}$ & 55.26 \\
\hline 7. & Rhizophora apiculata Blume. & $23.00 \mathrm{~b}$ & 74.05 \\
\hline 8. & Rhizophora conjucata Blume. & $47.33 \mathrm{~g}$ & 46.61 \\
\hline 9. & Suaeda maritima (Linn.)Dum & $26.33 \mathrm{c}$ & 70.30 \\
\hline 10. & Control & $88.66 \mathrm{i}$ & - \\
\hline
\end{tabular}

*Means of three replications

**The means followed by a common letter are not significantly different at $\mathrm{P}=0.05$ by DMRT

Table 5: In vitro antifungal activity of water extracts from mangrove plants against Macrophomina phaseolina.

pathogenic to cluster beans [33]. All the thirteen isolates of the root rot pathogen M. phaseolina produced cottony white or dull white mycelial growth on PDA medium. The isolates MP1, MP11, MP13 and MP18 significantly recorded the maximum $(90 \mathrm{~mm})$ mycelial growth, while it was the minimum $(75.00 \mathrm{~mm})$ in the case of MP5 [26]. These reports corroborates with that of the present findings.

\section{Antifungal activity}

Water extracts of nine mangrove plant species were screened against the root rot pathogen, $M$. phaseolina. Of these, water extracts of Salicornia brachiata $(21.33 \mathrm{~mm})$, Rhizophora apiculata $(23.00 \mathrm{~mm})$ and Suaeda maritima $(26.33 \mathrm{~mm})$ were found to be toxic to the fungus (Table 5) and were significantly superior $(\mathrm{P}=0.05)$ to other water extracts in reducing the colony growth of $M$. phaseolina. This clearly indicated that the mangrove leaf extracts (water) have antifungal property (Figure 6). 
Citation: Muthukumar A, Naveenkunar R, Venkatesh A (2014) Efficacy of Water Extracts of Some Mangrove Plants for Eco-friendly Management of Root Rot Disease of Groundnut. J Plant Pathol Microb 5: 243. doi:10.4172/2157-7471.1000243
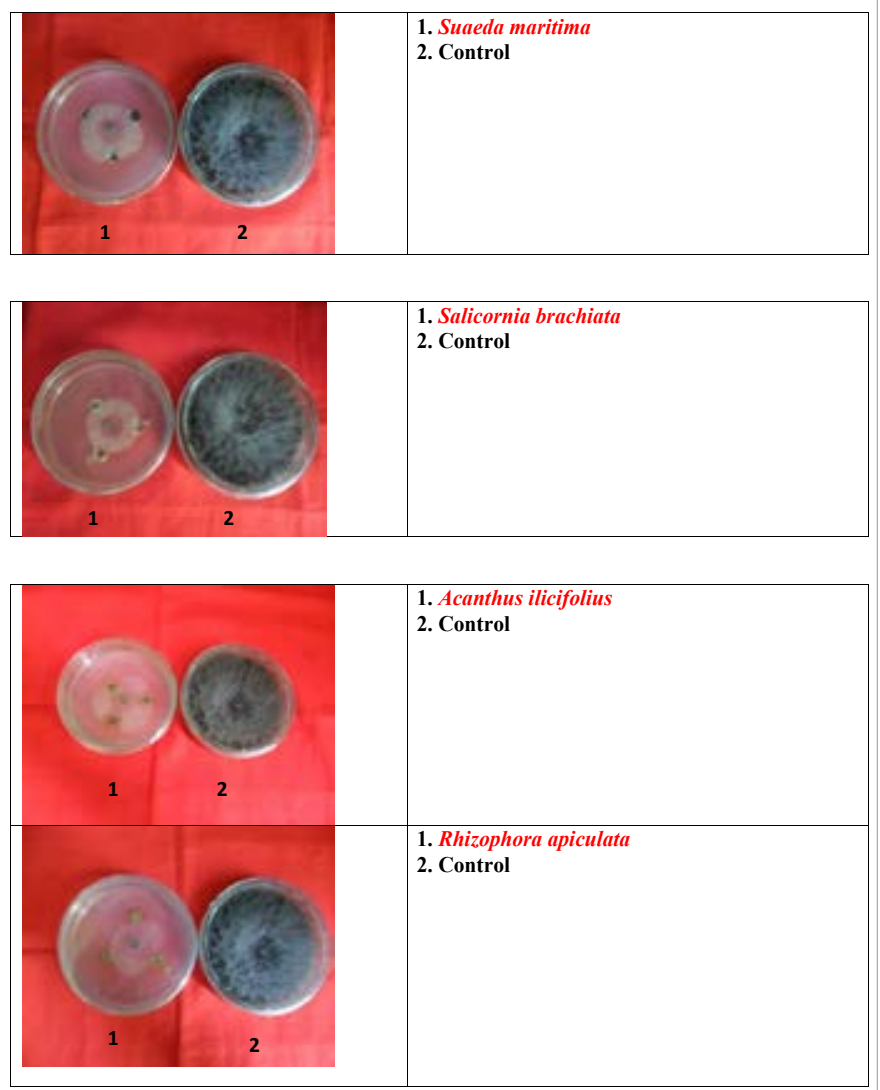

Figure 6: Antifungal activity of mangrove leaf extract against Macrophmina phaseolina.

Twenty four species of family asteraceae were tested against $M$. phaseolina. Maximum inhibition of M. phaseolina was caused by Eclipta alba followed by Launea aspleniifolia. In vitro studies indicated that plant leaf extracts of Adenocalymma alliaceum (77.20\%) and Allium sp. (74.71\%) demonstrated the highest inhibition of mycelial growth of M. phaseolina at $10 \%$ concentration [34]. The plant leaf extracts of Adenocalymma alliaceum (77.20\%) and Allium sp. (74.71\%) demonstrated the highest inhibition of mycelia growth of M. phaseolina (leaf blight of green gram) at $10 \%$ concentration [35]. This type of growth inhibition might be due to the presence of active principles/ chemical compounds (steroids, triterpenes, saponins, flavonoids, alkaloids, tannins and phenolics) present in the particular plant [25].

From the above results it is concluded that the water extracts obtained from marine leafs viz., Salicornia brachiata, Rhizophora apiculata and Suaeda maritima showed highest antifungal activity against Macrophomina phaseolina. This might be due to the presence antifungal metabolites present in the particular plant. In future, this will be identified by using GC-MS.

\section{References}

1. USDA Foreign Agricultural Service (2009): Table 13 Peanut Area, Yield, and Production Top ten producers of peanuts in 2008/2009.

2. Mayee CD, Datar VV (1988) Diseases of groundnut in the tropics. Review Trop PI Path 5: 169-198.

3. Ganesan S, Sekar R (2004) Biocontrol mechanism of Groundnut (Arachis hypogaea L.) Diseases-Trichoderma system. In: antimicrobial consumption and resistance in Staphylococcus aureus isolates from 15 hospitals in 14 countries. Microbial Drug Resistance 10: 169-176.
4. Mayee CD (1995) Current status and future approaches for management of groundnut disease in India. Indian Phytopathol 48: 389-401.

5. Raguchander T, Rajappan K, Prabakar K (1995) Evaluation of talc based product of Trichoderma viride for the control of black gram root rot. J Biol Control 9: 64-65.

6. Bharathi R, Vivekanandhan R, Harish s, Ramanathan A, Samiyappan R (2004) Rhizobacteria-based bio formulations for the management of fruit rot infection in chillies. Crop Prot 23: 835-843.

7. Chandrasekaran M, Kannathasan K, Venkatesalu V, Prabhaka, K (2009) Antibacterial activity of some salt marsh halophytes and mangrove plants against methicillin resistant Staphylococcus aureus. World J Microbiol Biotechnol 25: 155-160.

8. Byadgi A, Hegde RK (1985) Variation among the isolates or Rhizoctonia bataticola from different host plants. Indian Phytopath 38: 297-301.

9. Wu J, Xiao Q, Xu J, Li MY, Pan JY, et al. (2008) Natural products from true mangrove flora: source, chemistry and bioactivities. Nat Prod Rep 25: 955-981.

10. Barnett HL, Hunter BB (1972) Illustrated Genera of Imperfect Fungi. Minneapolis, Minn, USA: Burgress Publishing Company;

11. Mayee CD, Datar VV (1986) Phytopathometry. Technical Bulletin, Marathwada Agricultural University, Parbhani, p. 125.

12. Rangaswami G (1972) Diseases of crop plants in India. Prentice Hall of India Pvt. Ltd., New Delhi, 520 pp.

13. Riker AJ, Riker AS (1936) Introduction to research on plant diseases. John S.Swift, C.M.C., New York. 117 p

14. Sankar P (1994) Biological control of sesamum root rot caused by Macrophomina phaseolina (Tassi.) Goid. M.Sc.(Ag.) Thesis, Tamil Nadu Agricultural University, Coimbatore, India. 141p.

15. Shekhawat PS, Prasada R (1971) Antifungal properties of some plant extracts and inhibition of spore germination. Indian Phytopathol 24: 800-802.

16. Russell AD, Furr JR (1977) The antibacterial activity of a new chloroxyleno preparation containing ethylenediamine tetraacetic acid. J Appl Bacteriol 43: 253-260.

17. Irobi ON, Moo-Young M, Anderson WA (1996) Antimicrobial activity of Annatto (Bixa orellana) extract. International J Pharmacognosy 34: 87-90.

18. Gomez KA, Gomez AA (1984). Statistical Procedure for Agricultural Research John Wiley and Sons, New York, NY, USA.

19. Moradia AM, Khandar RR (2011) Loss of yield of groundnut (Arachis hypogaea L.) due to dry root rot (Macrophomina phaseolina) and their management under in vivo condition. International J Agrl Sci 7: 282-285.

20. Maiti S, Rauof MA, Sastry KS, Yadava TP (1985) A review of sesame diseases in India. Trop Pest Manage 31: 317-323.

21. Taya R S, Tripathi MH, Pawan MS (1988) Influence of soil type, soil moisture and fertilizers on the severity of chickepea dry root rot caused by Rhizoctonia bataticola (Taub) Butler. Indian J PI Pathol 18: 133-136.

22. Hooda I, Grover RK (1990) Environmental factors affecting control of Macrophomina phaseolina by fungicides on mungbean. PI Dis Res 5: 25-33.

23. Karunanithi K (1996) Studies on root rot of sesamum (Sesamum indicum L.) caused by Macrophomina phaseolina (Tassi) Goid. Ph.D. Thesis, Tamil Nadu Agricultural University, Coimbatore, India.

24. Umamaheshwari C (1991) Biological control of root rot of groundnut (Arachis hypogaea L.) caused by Macrophomina phaseolina (Maub.) Ashby. M.Sc. (Ag.) Thesis, Tamil Nadu Agricultural University, Coimbatore, India. $93 \mathrm{p}$.

25. Bandaranayake WM (1998) Traditional and medicinal uses of mangroves. Mangroves and Salt Marshes 2: 133-148.

26. Rajamohan K, Balabaskar P (2012) Survey on the incidence of groundnut root rot disease in cuddalore district of Tamil Nadu and assesing the cultura characters and pathogenicity of Macrophomina phaseolina. Asian $\mathrm{J} \mathrm{Sci}$ Technol 3: 90-94.

27. Devi TP, Singh RH (1998) Cultural variation of Macrophomina phaseolina isolates collected from Vigna mungo. Indian Phytopath 51: 292-293.

28. Shanmugasundaram $P$ (1992) Studies on charcoal rot of sunflower (Helianthus annus L.) caused by Macrophomina phaseolina (Tassi.) Goid. M.Sc.(Ag.) Thesis, Tamil nadu Agricultural University, Coimbatore, India. 85p. 
Citation: Muthukumar A, Naveenkunar R, Venkatesh A (2014) Efficacy of Water Extracts of Some Mangrove Plants for Eco-friendly Management of Root Rot Disease of Groundnut. J Plant Pathol Microb 5: 243. doi:10.4172/2157-7471.1000243

29. Rettinassababady C, Ramadoss N (2000) Biological protection of rice fallow blackgram against root rot disease (Macrophomina phaseolina). Legume Res 23: $246-248$

30. Ebenezer EG (1996) Studies on root rot of greengram (Vigna radiata L. Wilezek.) caused by Macrophomina phaseolina (Tassi.) Goid. Ph.D. Thesis, Coimbatore, India, p. 207

31. Singh A, Malhotra SK (1994) Effect of different media on cultural and morphological behaviour of Rhizoctonia solani causing web blight in winged bean. Crop Res 7: 129-132.

32. Ghosh SK, Sen C (1973) Comparitive physiological studies on four isolates of Macrophomina phaseolina. Indian Phytopathol 26: 615-621.
33. Sharmishha Purkayastha, Bhavneet Kaur, Neeraj Dilbaghi, Ashok Chaudhury (2004) Cultural and Pathogeinc variation in the charcoal root rot pathogen from cluster bean. Ann Agri Bio Res 9: 217-221.

34. Gautam K, Rao PB, Chauhan SVS (2003) Efficacy of some botanicals of the family compositae against Rhizoctonia solani (Kuhn.). J Mycol PI Pathol 33: 230-235.

35. Sundaramoorthy S, Murugapriya E, Gnanasingh Jesu Maharaja L, Alice D (2013) Induction of systemic resistance in green gram against leaf blight caused by Macrophomina phaseolina (Tassi.) Goid. African J Microbiol Res 7: 3976-3982. 